\title{
Monograms on the Capitals of S. Sergius at Constantinople.
}

The capitals of some of the columns on both the ground floor and gynaeceum level have sculptured monograms, and on the frieze of the lower order runs a long inscription, which is given in Salzenberg's Altchristliche Baudenkmale von Constantinopel. The monograms are similar to those on the capitals of Sta. Sophia, which have been

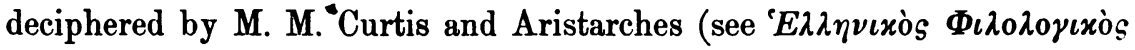
$\Sigma v ं \lambda \lambda o \gamma o s, \pi \alpha \rho \alpha \rho \tau \eta \mu \alpha$ for the year 1885 p. 13). The monograms can be arranged as follows.

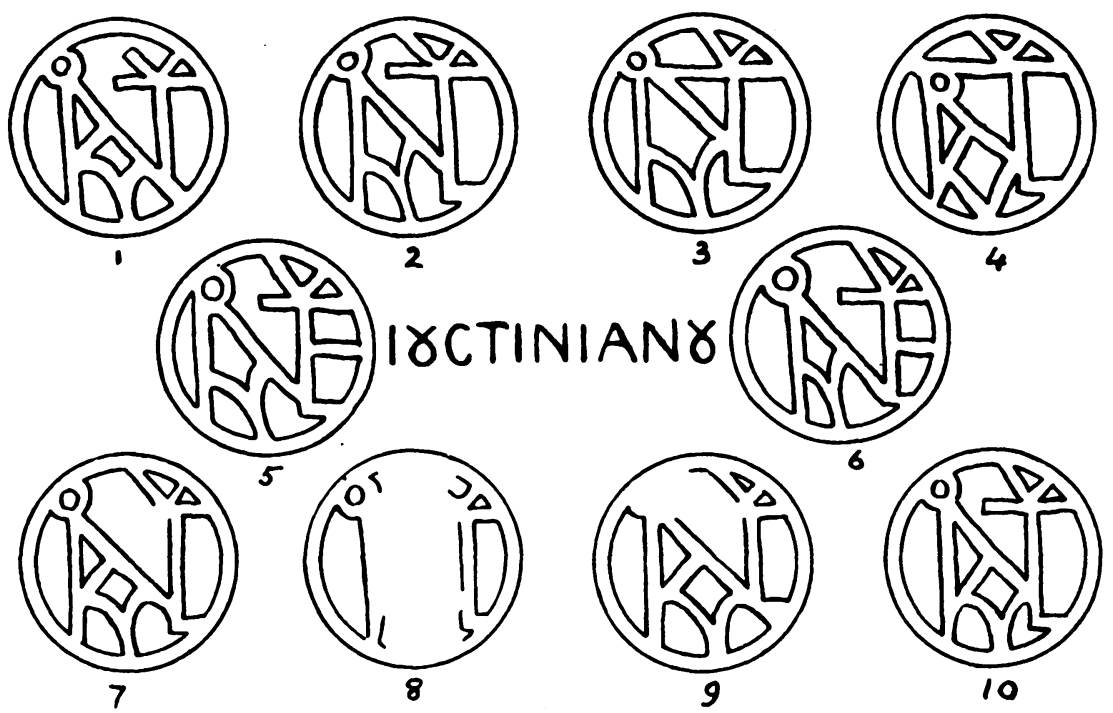

1-10 can be read "Justinian“. These are similar to those in Sta. Sophia, to others on the capitals of S. Irene, to a monogram on a sculptured bird in the Imperial Museum at Constantinople, and also to the coins of the Emperor, as figured by Sabatier (Histoire genérale des monnaies byzantines). Two of these 10 monograms contain an $\mathrm{E}$, 
as also two at Sta. Sophia, which may perhaps be due to a slovenly spelling.
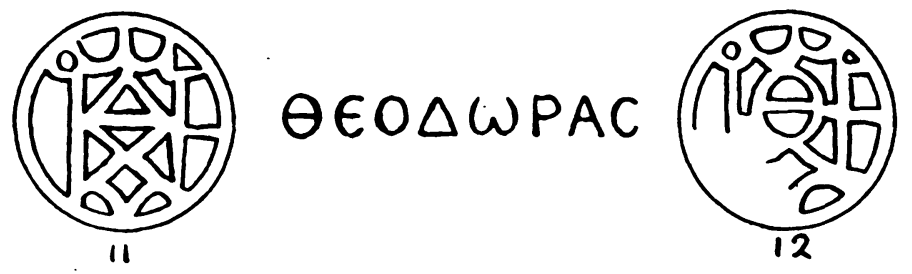

11-12 bear the monogram "Theodora". Examples of this can also be found on the capitals of Sta. Sophia.
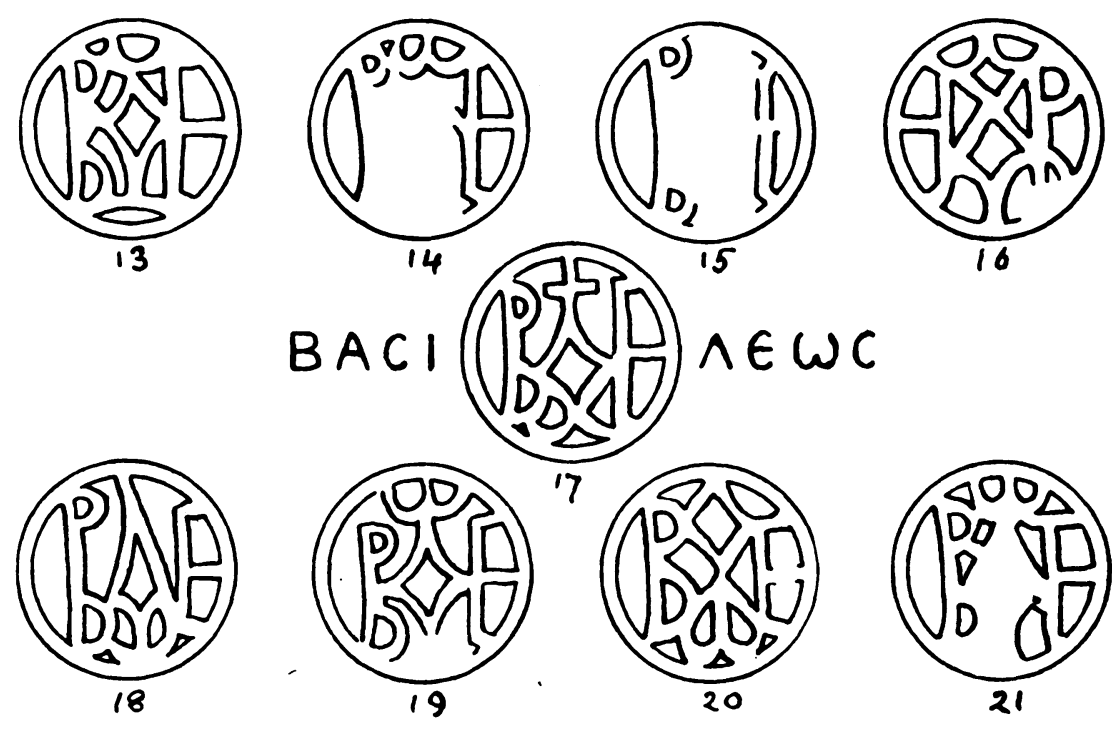

13-21 bear the monogram „of the king“. Examples of this can also be found on the capitals of Sta. Sophia.

The church of $\mathrm{S}$. Sergius, as we know from Procopius (de Aed. p. 186 ed. Bonn), was built by Justinian: probably, from its connection with the palace of Hormisdas, before the death of his uncle Justin I. This may account for the absence of the title "Augusta" as applied to Theodora, on the monograms of S. Sergius, while it occurs on those of Sta. Sophia, which was built when Justinian reigned supreme. S. Sergius and S. Bacchus, to whom the church was dedicated, were the warrior saints of Syria. There was a church built in their honour at Bosra in 512, A. D., and to their church at Sergiopolis the Empress Theodora sent a „cross ornamented with much 
108 I. Abt. H. Swainson: Monograms on the Capitals of S. Sergius at Constantinople gold and precious stones" (see Evagrius Hist. Eccles. IV cap. 28 and VI cap. 21).

Besides the plan, plates, and text in Salzenberg's Altchristliche Baudenkmale von Constantinopel, an historical description of the church

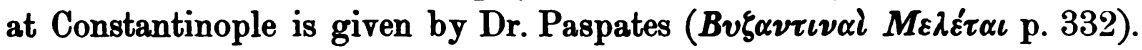
The church is now covered with whitewash, but Paspates says when

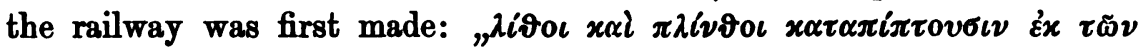

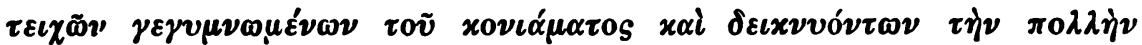

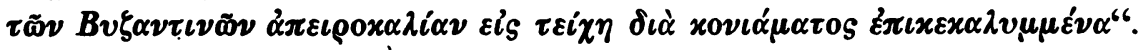

London.

H. Swainsou. 